\title{
7
}

\section{Profitability in a Sustainable Agricultural Production System: An Approach by the Soil and Water Conservation}

\author{
Idrissa Ouiminga
}

\subsection{Introduction}

For several decades, Africa has suffered severe degradation of its natural resources, limiting the development of agro-sylvo-pastoral productions (Pontanier et al. 1995; Thiombiano 2000). Rising temperatures and changes in rainfall patterns have direct effects on crop yields and indirect effects due to changes in water availability for irrigation (IFPRI 2009). According to the Intergovernmental Panel on Climate Change (2014), yield reductions of $10-25 \%$ and even more could become commonplace by 2050 .

The continent is experiencing difficult climatic conditions, relatively high population growth and a continuing decline in soil fertility. Repeated droughts and inadequate natural resource exploitation practices have resulted in the destruction of the vegetation cover and the exposure of the

I. Ouiminga $(\bowtie)$

University Ouaga II, Ouagadougou, Burkina Faso

(C) The Author(s) 2018 
soil to the weather (wind and rain). Since sub-Saharan agriculture is predominantly rain-fed, it is highly vulnerable to rainfall. (FAO 2010).

Thus, in the Sahelian regions, the areas of degraded and denuded soils are considerable, sometimes reaching significant proportions in northern Burkina Faso, with over $24 \%$ of the total agricultural area (Barro et al. 2005). For this country, $24 \%$ of arable land is severely degraded, and an average of $31 \%$ of annual rainfall is lost through runoff, posing a threat to food security in the medium and long term. Erosion of arable land, whether due to runoff or cultivation tools (Dibouloni 2004), is one of the factors contributing to declining agricultural yields (Roose et al. 1993).

To reverse this trend and achieve more sustainable patterns of exploitation, many actions to combat land degradation and desertification are needed. This includes assessing the effects of public or private investment in the management of natural resources through the transformation of production systems and the environment in the Sahel (Botoni and Reij 2009). This is why major financial and human investments have been made for the development and dissemination of soil and water conservation (SWC) techniques, which are considered as tools for soil protection and restoration. These techniques, by reducing erosion, contribute to the use of local resources (labor, stones, etc.) and waste reduction (animal and/or animal waste compost) and do not undermine the integrity of living beings.

The practice of soil and water conservation techniques is aimed at restoring soils and increasing yields and therefore affecting the environmental component. The social aspect is taken into account in the use of this practice because it constitutes a source of temporary income for the labor used. Moreover, at the social level, water and soil conservation techniques contribute to a reduction of migrations and a return of migrants (Ouedraogo et al. 2008).

However, nowadays it is important to include the notions of profitability in order to be able to take the appropriate decisions of management while taking into account the financial capacities of the targeted populations. However, even if the profitability of these techniques in terms of yield is proved, financially the question remains in the face of the 
lack of financial means available to the farmer, such as funds available for investment, lack of liquidity, work, and the earth. Indeed, costs related solely to labor are estimated between $€ 150$ and $€ 230$ per hectare (Barro et al. 2005). The evaluation of the financial profitability of soil and water conservation techniques in the municipality of Yalgo is the subject of our study.

Despite efforts by researchers over decades, the socio-economic impacts of investments in natural resource management (NRM) have been shown to be yield-positive (Ganaba 2005; Sawadogo H. 2008) but the returns on investments are varied, given the means invested for their implementation. Financial support through projects allows farmers to adopt them, while on an individual basis its facts are quite rare (Sanogo 2012). Baumgart-Getz et al. (2012) show that financial capacity is a basic factor of agricultural investment, which is why the producer expects a return on investment. Thus, the identification of the most profitable soil and water conservation technique in a Sahelian context is a tool for decision-making both for the promotion of sustainable agriculture in such climates and for the various anti-erosion projects and programs. Therefore, the determination of the social costs of production by SWC and the comparative evaluation of the benefits make it possible to identify the best technique in the Sahelian context.

Other authors have highlighted the use of practices related to the conservation of natural resources (soil, water, etc.). Gedikoglu and McCann (2007) who worked on conservation practices and Rodríguez-Entrena and Arriaza (2013) who worked on practices related to conservation agriculture all used the turnover realized by producers as indicators of wealth. The choice of investment indicator can also be the level of income (Mariano et al. 2012) or social capital (Gedikoglu et al. 2011); we opt for a more delicate measure, that of net profit.

SWC is the set of measures, which, while developing natural resources, tend to maintain (and if possible increase) the potential for production, the soil and water being the fundamental elements of these potentialities.

There are a large number of SWC techniques in our study area, the latter being mainly biological and physical.

Many organic techniques include organic fertilization and mulching. 
Organic fertilization by compost or manure is fairly widespread. This is exclusively the application of raw manure or compost in cultivation plots (Dibouloni 2004). This spreading is also done by the parking of animals on the areas concerned. Sometimes parking is accompanied by contracts of fertilization between the breeders and the farmers.

Mulching consists of using mowed grass or crop residues that are spread on land to be recovered or improved during the dry season. This reduces the impact of water drops on the soil, reduces runoff, increases water infiltration into the soil, improves weed control, and the activity of microorganisms. The latter will favor the decomposition of straw or stems, thus contributing to the improvement of soil fertility (Ouédraogo 2005). However, the impact of mulching on yields, remains very low. Data collected at Donsin show an increase in yield of about $5 \%$ for mulching and 2\% for burned mulch (Ouédraogo 2005).

Physical techniques include structures constructed or dug with the aim of creating obstacles to runoff and reducing soil erosion (Botoni and Reij 2009), including the basin, half-moons and stony cords.

The Zaï is an old peasant technique perfected by the various actors with the peasants. They are seed holes about 30 to $40 \mathrm{~cm}$ in diameter and 10 to $15 \mathrm{~cm}$ deep. The distance between the holes is 70 to $80 \mathrm{~cm}$, which gives about 10,000 holes per ha. These holes are dug perpendicularly to the slope and staggered.

The half-moon is a practice of collection of runoff consisting of digging a basin in the form of a semicircle with a diameter between $2 \mathrm{~m}$ and $6 \mathrm{~m}$ and a depth of $15 \mathrm{~cm}$ to $20 \mathrm{~cm}$ (Kini 2007). A half-moon occupies a theoretical area of 1.57 to $14.13 \mathrm{~m}^{2}$ and the number of half-moons per hectare is of the order of 312 to 417 according to the spacing between them (Ouédraogo et al. 2008).

The construction of stony cords or stone bunds is a semi-permeable structure consisting of two to three levels/rows of stones arranged in a contour (Lompo and Ouédraogo 2006). This technique slows down runoff so that it infiltrates more quickly.

In general, investments in natural resource management have important impacts and therefore contribute to increasing productivity and agricultural production. That result leads to increasing food security and improving of the population's income (Botoni and Reij 2009; Ouédraogo 
et al. 2008 ${ }^{1}$ ). According to the same authors, on the social level, soil and water conservation techniques contribute to a reduction of migrations and a return of migrants. At the economic level, the quantification of impacts reveals that investments are very profitable, $37-107 \%$ for the zaï, $23 \%$ for the stony ropes and $145 \%$ for the half-moons.

There is therefore no doubt about the positive effects of SWC techniques, which are in the majority of cases supported by public investment projects or programs. If it is assumed that public investments or those through projects and programs are insufficient for the millions of farmers in developing countries, what about their profitability for financing from the farmer? What technique is there to ensure a good return on investment?

\subsection{Methodology}

There are several approaches to analyzing the financial viability of using natural resource management techniques. Economically, several methods of decision-making as to the justification of the opportunity cost of capital and the rate of social preference over time are possible.

The SWC techniques can be considered a club good, that means not a rival good but exclusive one (Samuelson 1954), insofar as the farmer who does not pay costs related to these techniques is excluded from their use. To do this, the farmer makes his reasoning rational: he carries out a benefit-cost analysis or a cost-benefit analysis through the determination of net present value (NPV) or internal rate of return (IRR).

The use of the NPV in such a case makes it possible to obtain an estimate of the net value of all the revenues generated by the use of these techniques over time.

$$
\mathrm{VAN}=-I_{0}+\sum \frac{R_{t}-C_{t}}{(1+i)^{n}} \pm \sum \frac{\mathrm{EXT}_{t}}{(1+i)^{n}}+\frac{\mathrm{Vd}}{(1+i)^{n}}=-I_{0}+\sum \frac{\mathrm{CF}_{t}}{(1+i)^{n}}
$$

where $I_{0}$ is the economic cost of the initial investment; $\mathrm{R}_{t}$ the exploitation Income; And economic operating costs; $\mathrm{EXT}_{t}$ positive or negative 
externalities; I the discount rate; $\mathrm{Vd}$ the residual value of the project; $\mathrm{CF}_{t}$ the cash flow of the investment; $t$ the year of the project and $n$ the project horizon.

As for the IRR (Ouédraogo et al. 2008), it gives the rate for which the NPV is zero. It is as follows:

$$
\mathrm{VAN}=0 \Leftrightarrow I_{0}=\sum \frac{\mathrm{CF}_{t}}{(1+\mathrm{TRI})^{n}}
$$

One of the requirements of these two tools is the determination of the discount rate that is essential to their use so that an incorrect estimate of this rate leads to the obtaining of biased indicators. Moreover, the IRR would be relevant only if it is higher than the bank borrowing rate, which is not very evident in the context of developing countries. As financial risk is high, financial institutions take precautions and even discourage borrowing for such investments (Abramovay 2002).

Thus, the approach we use is the marginal rate of return (MRR) used by Crawford et al. (1991), Bourdon (1994) for similar studies.

The objective of this method is to determine the cost-effectiveness of different methods of restoring degraded lands. This analysis therefore aims to contribute to the formulation of recommendations that the farmer can adopt. Its application uses data collected over several years in real situations and meets the concept of sustainability. Indeed, it combines the economic aspects through the search for the treatment, giving the highest net benefit, the environmental aspects through treatments allowing a better management of the natural assets and social aspects through the workforce mobilized for the implementation and the sedentarization of the populations that it can bring.

The stages of economic analysis of SWC trials consist of four main parts:

- Preparation of the partial budget for each treatment

- The determination of the "higher" treatments whose profitability justifies the adoption by the farmer

- The calculation of the MRR for each "higher" treatment 
- The determination, among the treatments considered to be sufficiently profitable, of which one seems to be the most interesting given the means available to the farmer and his objectives not yet taken into account in the analysis

\subsubsection{The Preparation of the Partial Budget}

In partial budgets, the net benefit of change is evaluated from current practices to recommended practices. For this analysis, we use costs and prices prevailing in the local market to estimate costs and revenues corresponding to the level of a given technical innovation.

\subsubsection{The Determination of "Higher" Treatment}

The identification of higher treatments is the first part of a marginal analysis. The goal of this task is to eliminate the lower treatments from the subsequent marginal analysis. Treatment is dominated or inferior when there is at least one other treatment with a higher net benefit for lower or equal loads. Treatment is therefore non-dominated, or superior, when there are no other options offering a higher net benefit for less than or equal loads.

\subsubsection{The Calculation of the Marginal Rate of Return}

The marginal rate of return for all treatments is calculated as the ratio (in percentage) of additional net income to the incremental costs associated with the adoption of an increasing level of input. The term "marginal" refers to the difference between the value of a given treatment and that of the lowest-ranking treatment; it is a ratio of variation to the margin. The marginal rates of return are compared with the target rate to identify satisfactory treatments. Treatment that meets the target rate is selected with the highest net benefit. We continue to change to another level of input provided that the MRR is above the target rate. In other words, the marginal rate of return indicates where expenditure ceases to provide a satisfactory increase in income, expressed as a percentage of invested funds. 


\subsubsection{Choice of Preferred Treatment}

This step consists of choosing the treatment with the highest net profit and a MRR equal to or higher than the target rate.

\subsubsection{Treatment}

As presented in the problem, six combinations of treatments for soil and water conservation were applied compared to a control site without any treatment. The cultures produced are millet of variety IKMP5 and sorghum of variety Kapelga. The different treatments are as follows:

T1: producer's practice

T2: SR + Zaï + organic fertilizer (SR + Zaï + fo)

T3: SR + HM + organic fertilizer $(S R+H M+f o)$

T4: SR + Zaï + organic fertilizer + Urea (SR + Zaï + fo + Urea $)$

T5: SR + HM + organic fertilizer + Urea (SR + HM + fo + Urea)

T6: SR + Zaï + organic fertilizer + Urea + NPK (SR + Zaï + fo + Urea + NPK) $\mathrm{T} 7: \mathrm{SR}+\mathrm{HM}+$ organicfertilizer + Urea + NPK $(\mathrm{SR}+\mathrm{HM}+$ fo + Urea + NPK $)$

SR = Stony ropes; HM = Half-moon; NPK = Nitrogen, Phosphorous, Potassium

\subsection{Study Area and Data}

\subsubsection{Study Area}

Our study focuses on testing SWC in Burkina Faso in Yalgo commune, more than $200 \mathrm{~km}$ north of the capital Ouagadougou. With an estimated density of 74.73 inhabitants $/ \mathrm{km}^{2}$ in 2014 (NISD $2015^{2}$ ), the municipality has a predominantly young population with a gender distribution of about $51 \%$ women and $49 \%$ men.

The basic activity is mainly agricultural with a predominance for food crops. In general, agriculture in the area is subject to severe land degrada- 
tion, the grown areas are fragmented and their productivity is low. The crops commonly practiced by the populations are cereals such as millet, sorghum, corn, vouandzou.

Yalgo is one of the localities selected by the Institute of the Environment and Agricultural Research (INERA) as part of the project to improve water management in rain-fed systems to ensure food security in Burkina Faso (Improved water management in systems/AGES). The rainfall is typical of the Sudano-Sahelian climate, it is between $400 \mathrm{~mm}$ and $600 \mathrm{~mm}$ per year and the municipality has a single permanent watercourse. In this commune, the project covers four villages (Yalgo, Kario, Mamanguel and Taparko). The natural environment has a difficult context in the management of natural resources due to the arid and very hot climate.

\subsubsection{Data}

The data used for the work are mainly primary data. They range from 2014 to 2016 and cover the four villages of the municipality of Yalgo.

The characteristics of the primary data are summarized in Table 7.1.

\section{- Primary data}

The support we used to collect the primary data is the questionnaire. For the collection of primary data, a questionnaire allowed us to carry out a survey of 45 producers who took part in the AGES/INERA project. This survey takes into account the socio-personal, economic and institutional characteristics of the producers. It situates us on the different costs and revenues relative to the different technical options for water and soil conservation in order to determine their profitability.

It should be noted that all producers do not have access to credit, have received training in techniques for recovering degraded land, own their cultivated land, and almost all have access to the market. 
Table 7.1 Description of primary data characteristics

\begin{tabular}{lllll}
\hline & Variables & Modalities & Size & $\%$ \\
\hline $\begin{array}{c}\text { Socio-personal } \\
\text { characteristics }\end{array}$ & Sex & $0=$ man & 43 & 96 \\
& & $1=$ woman & 2 & 4 \\
& Perception & $0=$ bad & 0 & 0 \\
& & $1=$ good & 45 & 100 \\
& Education & $0=$ no & 43 & 96 \\
& Age & $1=$ yes & 2 & 4 \\
& & Average $=48$ & Min & 25 \\
& Active persons & Average $=5$ & Max & 71 \\
Economic & Market access & $0=$ no & Max & 1 \\
characteristics & & $1=$ yes & 1 & 2 \\
& Secondary activities & $0=$ no & 0 & 98 \\
& & $1=$ yes & 45 & 0 \\
& Agricultural material & $0=$ no & 38 & 84 \\
& & $1=$ yes & 7 & 16 \\
& Exploited area & Average $=4.9$ ha & Min & 2 ha \\
& & & Max & 8.5 ha \\
Institutional & Credit access & $0=$ no & 45 & 100 \\
characteristics & & $1=$ yes & 0 & 0 \\
& Training & $0=$ no & 0 & 0 \\
& & $1=$ yes & 45 & 100 \\
& Land tenure & $0=$ no & 0 & 0 \\
& & $1=$ yes & 45 & 100 \\
& Member of & $0=$ no & 45 & 100 \\
& association & $1=$ yes & 0 & 0 \\
\hline
\end{tabular}

Source: Yalgo Surveys 2014, 2015

\section{- Secondary data}

For yields, we used the secondary data collected by the AGES project (2014-2016). Data on the costs of implementing SWC technologies (zaii, demi-lunes and stony rocks) ${ }^{3}$ are mainly obtained from the Special Program for the Conservation of Water and Soils/Agroforestry (CES/ AGF). The price of the various speculations (millet, sorghum) applied in the framework of project are from the cereals market information system of 2015 . 


\subsection{Results and Discussions}

\subsubsection{Partial Budgets and Higher Treatments}

As indicated in the methodology, the preparation of partial budgets is the first step in the process. They are set out in Table 7.2.

It is noted in Table 7.2 that treatment with the highest yield (T6) is characterized by the highest net benefit. It is also noted that peasant practice (T1) offers a higher yield than the T3 treatment. Also T1 (practice without arrangements) makes it possible to have a net profit greater than that of T3, T5 and T7. This may be explained, on the one hand, by the fact that the T3, T5 and T7 techniques have very high loads and insufficient yields. On the other hand, this phenomenon could be explained by the fact that the half-moon technique is less adapted to the culture of millet compared to the technique of the zai in the commune of Yalgo.

The partial budget of soil and water conservation techniques under Sorghum also shows that the technique with the highest yield (T7) also has the greatest net benefit. However, net income is not always proportional to performance. Indeed, it can be seen that peasant practice (T1), although performing below the T2 and T3 techniques, offers a higher net benefit than the latter. This may be because techniques T2 and T3 involve more loads than $\mathrm{T} 1$.

The identification of higher salaries, that is, salaries for which there is no other option offering a higher net profit for lower or equal charges, is made from the comparative results of profits and Costs.

Table 7.4 shows that the T3, T5 and T7 technologies are dominated because $\mathrm{T} 1$ allows a higher profit at a lower cost. This analysis of dominance under millet culture shows that only T2, T4 and T6 technologies can be considered as promising in terms of farmer practices (T1).

It is apparent from Table 7.5 that under sorghum cultivation only the $\mathrm{T} 1, \mathrm{~T} 5$ and $\mathrm{T} 7$ technologies are superior.

By continuing the determination of the higher treatments between the two speculations, the results are presented to Table 7.6.

The comparative analysis between the higher treatments under sorghum and millet culture reveals that only the cultivation of millet has 
Table 7.2 Partial budget for water and soil conservation techniques under cultivation of one hectare of Millet

\begin{tabular}{|c|c|c|c|c|c|c|c|}
\hline \multirow[b]{2}{*}{ Topics } & \multicolumn{7}{|c|}{ Treatments } \\
\hline & T1 & $\mathrm{T} 2$ & T3 & $\mathrm{T} 4$ & $\mathrm{~T} 5$ & T6 & $\mathrm{T7}$ \\
\hline $\begin{array}{l}\text { Average yield } \\
(\mathrm{kg} / \mathrm{ha})\end{array}$ & 620 & 2206 & 550 & 3197 & 650 & 3684 & 1100 \\
\hline $\begin{array}{l}\text { Average yield } \\
\text { readjusted } \\
\text { (kg/ha) }\end{array}$ & 558 & 1985 & 495 & 2877 & 585 & 3315 & 990 \\
\hline $\begin{array}{l}\text { Production } \\
\text { value (FCFA) }\end{array}$ & 128,898 & 458,627 & 114,345 & 664,656 & 135,135 & 765,904 & 228,690 \\
\hline \multicolumn{8}{|c|}{ Monetary variable cost (FCFA) } \\
\hline $\begin{array}{l}\text { Cost per unit } \\
\text { of organic } \\
\text { fumure }\end{array}$ & 0 & 6000 & 6000 & 6000 & 6000 & 6000 & 6000 \\
\hline $\begin{array}{l}\text { Cost per unit } \\
\text { of Urea }\end{array}$ & 0 & 0 & 0 & 18,000 & 18,000 & 18,000 & 18,000 \\
\hline $\begin{array}{l}\text { Cost per unit } \\
\text { of NPK }\end{array}$ & 0 & 0 & 0 & 0 & 0 & 25,000 & 25,000 \\
\hline $\begin{array}{l}\text { Total variable } \\
\text { cost }\end{array}$ & 0 & 6000 & 6000 & 24,000 & 24,000 & 49,000 & 49,000 \\
\hline \multicolumn{8}{|c|}{ Non-monetary variable cost } \\
\hline $\begin{array}{l}\text { Cost of } \\
\text { realization } \\
\text { of stone }\end{array}$ & 0 & 77,130 & 77,130 & 77,130 & 77,130 & 77,130 & 77,130 \\
\hline $\begin{array}{l}\text { Cost of } \\
\text { realization } \\
\text { of zaï }\end{array}$ & 0 & 29,600 & 0 & 29,600 & 0 & 29,600 & 0 \\
\hline $\begin{array}{l}\text { Cost of } \\
\text { realization } \\
\text { of HM }\end{array}$ & 0 & 0 & 27,200 & 0 & 27,200 & 0 & 27,200 \\
\hline $\begin{array}{l}\text { Total } \\
\text { opportunity } \\
\text { cost }\end{array}$ & 0 & 106,730 & 104,330 & 106,730 & 104,330 & 106,730 & 104,330 \\
\hline $\begin{array}{l}\text { Total variable } \\
\text { cost }\end{array}$ & 0 & 112,730 & 110,330 & 130,730 & 128,330 & 155,730 & 153,330 \\
\hline Net benefit & 128,898 & 345,897 & 4015 & 533,926 & 6805 & 610,174 & 75,360 \\
\hline
\end{tabular}

Source: Survey 2015

$\mathrm{NPK}=400 \mathrm{CFA} / \mathrm{kg} ;$ Urea $=360 \mathrm{FCFA} / \mathrm{kg} ; \mathrm{FO}=1.2 \mathrm{FCFA} / \mathrm{kg}, 231 \mathrm{~F} / \mathrm{Kg}$ of millet

FCFA - Franc of the Financial Communities of Africa 
Table 7.3 Partial budget of SWC techniques under one hectare of Sorghum

\begin{tabular}{|c|c|c|c|c|c|c|c|}
\hline \multirow[b]{2}{*}{ Topics } & \multicolumn{7}{|c|}{ Treatments } \\
\hline & T1 & $\mathrm{T} 2$ & $\mathrm{~T} 3$ & $\mathrm{~T} 4$ & $\mathrm{~T} 5$ & T6 & $\mathrm{T7}$ \\
\hline $\begin{array}{l}\text { Average yield } \\
(\mathrm{kg} / \mathrm{ha})\end{array}$ & 583 & 1100 & 900 & 1407 & 2150 & 2522 & 2800 \\
\hline $\begin{array}{l}\text { Average yield } \\
\text { readjusted } \\
\text { (kg/ha) }\end{array}$ & 524 & 990 & 810 & 1266 & 1935 & 2269.8 & 2520 \\
\hline $\begin{array}{l}\text { Production } \\
\text { value (FCFA) }\end{array}$ & 91,823 & 173,250 & 141,750 & 221,603 & 338,625 & 397,215 & 441,000 \\
\hline \multicolumn{8}{|c|}{ Monetary variable cost (FCFA) } \\
\hline $\begin{array}{l}\text { Cost per unit of } \\
\text { organic } \\
\text { fumure }\end{array}$ & 0 & 6000 & 6000 & 6000 & 6000 & 6000 & 6000 \\
\hline $\begin{array}{l}\text { Cost per unit of } \\
\text { Urea }\end{array}$ & 0 & 0 & 0 & 18,000 & 18,000 & 18,000 & 18,000 \\
\hline $\begin{array}{l}\text { Cost per unit of } \\
\text { NPK }\end{array}$ & 0 & 0 & 0 & 0 & 0 & 25,000 & 25,000 \\
\hline $\begin{array}{l}\text { Total variable } \\
\text { cost }\end{array}$ & 0 & 6000 & 6000 & 24,000 & 24,000 & 49,000 & 49,000 \\
\hline \multicolumn{8}{|c|}{ Non-monetary variable cost } \\
\hline $\begin{array}{l}\text { Cost of } \\
\text { realization of } \\
\text { stone }\end{array}$ & 0 & 77,130 & 77,130 & 77,130 & 77,130 & 77,130 & 77,130 \\
\hline $\begin{array}{l}\text { Cost of } \\
\text { realization } \\
\text { of zaï }\end{array}$ & 0 & 29,600 & 0 & 29,600 & 0 & 29,600 & 0 \\
\hline $\begin{array}{l}\text { Cost of } \\
\text { realization } \\
\text { of HM }\end{array}$ & 0 & 0 & 27,200 & 0 & 27,200 & 0 & 27,200 \\
\hline $\begin{array}{l}\text { Total } \\
\text { opportunity } \\
\text { cost }\end{array}$ & 0 & 106,730 & 104,330 & 106,730 & 104,330 & 106,730 & 104,330 \\
\hline $\begin{array}{l}\text { Total variable } \\
\text { cost }\end{array}$ & 0 & 112,730 & 110,330 & 130,730 & 128,330 & 155,730 & 153,330 \\
\hline Net benefit & 91,823 & 60,520 & 31,420 & 90,873 & 210,295 & 241,485 & 287,670 \\
\hline
\end{tabular}

Source: Survey 2015 
Table 7.4 Identification of higher treatments under millet crop

\begin{tabular}{llll}
\hline & Variable cost (FCFA) & Net benefit (FCFA) & Superior? \\
\hline T1 & 0 & 128,898 & Oui \\
T2 & 112,730 & 345,897 & Oui \\
T3 & 110,330 & 4015 & Non \\
T4 & 130,730 & 533,926 & Oui \\
T5 & 128,330 & 6805 & Non \\
T6 & 155,730 & 610,173 & Oui \\
T7 & 153,330 & 75,360 & Non \\
\hline
\end{tabular}

Source: Survey 2015

Table 7.5 Identification of higher treatments under sorghum crop

\begin{tabular}{llll}
\hline & Variable cost (FCFA) & Net benefit (FCFA) & Superior? \\
\hline T1 & 0 & 91,822 & Oui \\
T2 & 112,730 & 60,520 & Non \\
T3 & 110,330 & 31,420 & Non \\
T4 & 130,730 & 90,872 & Non \\
T5 & 128,330 & 210,295 & Oui \\
T6 & 155,730 & 241,485 & Non \\
T7 & 153,330 & 287,670 & Oui \\
\hline
\end{tabular}

Source: Survey 2015

Table 7.6 Comparison of higher treatments under millet and sorghum crop

\begin{tabular}{lccl}
\hline & Total variable cost & Net benefit & Superior? \\
\hline T1 (millet) & 0 & 128,898 & Oui \\
T2 (millet) & 112,730 & 345,897 & Oui \\
T4 (millet) & 130,730 & 533,926 & Oui \\
T6 (millet) & 155,730 & 610,173 & Oui \\
T1 (sorghum) & 0 & 91,822 & Non \\
T5 (sorghum) & 128,330 & 210,295 & Non \\
T7 (sorghum) & 153,330 & 287,670 & Non \\
\hline
\end{tabular}

Source: Survey 2015 
advantages. Indeed, the cultivation of millet offers higher profits than the sorghum crop for lower or equal variable costs.

\subsubsection{Analysis of Profitability}

The first step is to calculate MRR as shown in Table 7.7. It is the ratio of marginal net profit to marginal variable costs, expressed in relative terms.

These results at the margin show that for a farmer who passes from treatment T2 to treatment T4 the marginal gains (1044) are greater than when passing from $\mathrm{T} 1$ to $\mathrm{T} 2$ and/or from T4 to T6. The slope of the dominant options curve reflects the same result when linking only the top treatments (see Fig. 7.1).

Thus a major result is that it is not the treatment with the highest net benefit (T6) that gives the highest MRR but rather the T4 treatment.

\subsubsection{Choice of Target Rate and Choice of Preferred Treatment}

For African countries, the value-cost ratio standard accepted by Food and Agriculture Organisation (FAO) is 2; that means an MRR of 100\%. This implies for the producer at least a doubling of the gains in relation to his investments. By observing the different MRR, this condition is fulfilled in the various cases (Table 7.7).

Based on this, the best combination of soil and water conservation techniques is $\mathrm{T} 6$ treatment.

Table 7.7 Marginal profitability rate

\begin{tabular}{|c|c|c|c|c|c|}
\hline & $\begin{array}{l}\text { Total variable } \\
\text { cost }\end{array}$ & $\begin{array}{l}\text { Marginal variable } \\
\text { cost }\end{array}$ & Net benefit & $\begin{array}{l}\text { Net marginal } \\
\text { profit }\end{array}$ & MPR \\
\hline T6 & 155,730 & 25,000 & 610,173 & 76,247 & 305 \\
\hline T4 & 130,730 & 18,000 & 533,926 & 188,029 & 1044 \\
\hline $\mathrm{T} 2$ & 112,730 & 112,730 & 345,897 & 216,999 & 193 \\
\hline T1 & 0 & & 128,898 & & \\
\hline
\end{tabular}

Source: Survey 2015 


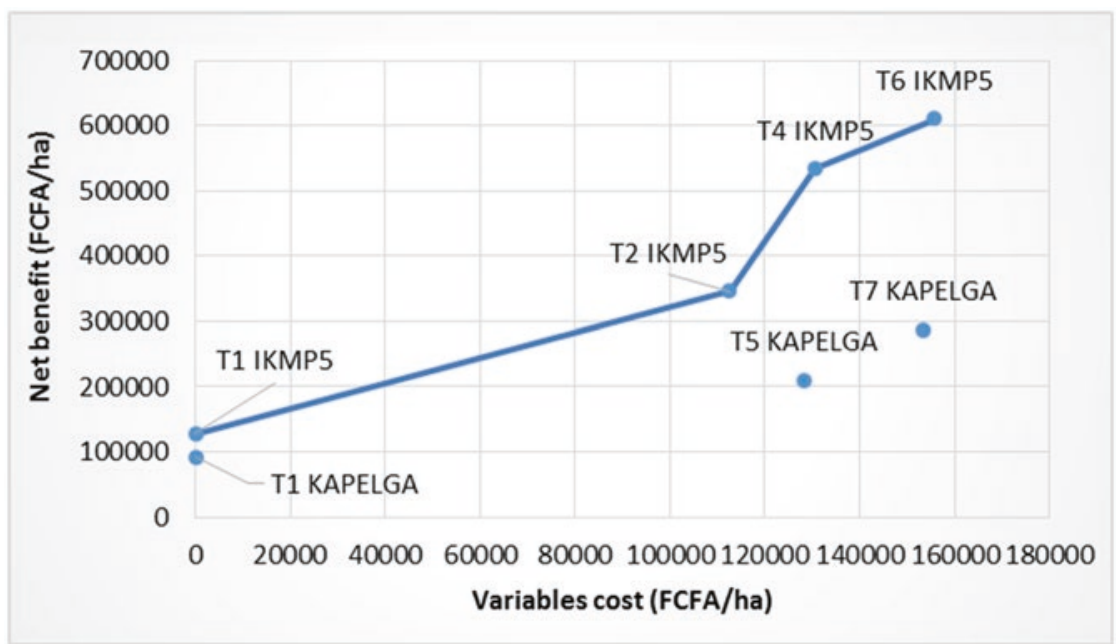

Fig. 7.1 Curve of dominant options. Source: Authors based on data of Survey 2015

All treatments with MRR equal to or above the target rate are satisfactory. Among the satisfactory treatments, the final choice of the treatment to be recommended will be determined by determining the treatment with the highest net benefit. Thus, with a view to profitability and in the context of better management of natural production assets, the choice will be made for T6 treatment $(\mathrm{SR}+\mathrm{Zaï}+\mathrm{fo}+$ urea $+\mathrm{NPK})$ under millet culture. The material is a determining factor in the use of these techniques. The possession of small ruminants favored the adoption of zai and the cattle were crucial for the adoption of stony ropes and "zaï and stony ropes". Not only is financial profitability guaranteed, but environmental recovery of the natural assets of land is an important achievement. It should be noted that the use of stony cords by the workforce that this requires entails a redistribution of income which is an important element of the social dimension.

Taking into account that producers have almost all access to the market and all own their growing areas, it can be assumed that the sale of millet, grown under T6, at the market price would be a benefit for producers. Such a result is termed sustainable because, in addition to the recorded 
economic and social results, soil restoration is ensured by stony ropes, Zaï and various fertilizers.

Thus, investments in natural resource management can be said to induce high levels of profitability, improve biodiversity and contribute to improving people's standard of living.

\subsubsection{Hypothesis of Pessimistic Climate Variability}

The initial estimates were made on the basis of the adjusted average returns so as not to inflate the results. In this case, a pessimistic climatic variability is taken into account with a $10 \%$ reduction in adjusted yields, which leads to an appreciation of the fallout in a scenario sufficiently alarmist to obtain the most realistic results in case of bad rainfall. The budgets estimated according to techniques and by speculation with pessimistic hypothesis are annexed to Table 7.8.

This table shows that the higher treatments in this scenario of poor rainfall are identical to those obtained in average rainfall conditions: $\mathrm{T} 1$, T2, T4 and T6 for millet and T1, T5 and T7 for sorghum. ${ }^{4}$

The comparison of the different higher treatments for both speculations is made to determine the best sustainable practice. ${ }^{5}$

The estimation in periods of unfavorable rainfall shows that the results achieved are less important from the financial point of view, but the observations remain the same as it is the combination T4 $(\mathrm{SR}+$ Zaï + organic fertilizer + Urea $)$ which helps to obtain the highest marginal profit for the cultivation of millet.

\subsection{Conclusion}

A zone severely degraded by climatic factors (decrease in rainfall, winds, runoff) and at the edge of the Sahel, Yalgo is a Burkina Faso locality with a cereal deficit.

Various SWC techniques have been put into practice by research in order to contribute to increased yields and thus financial profitability. 


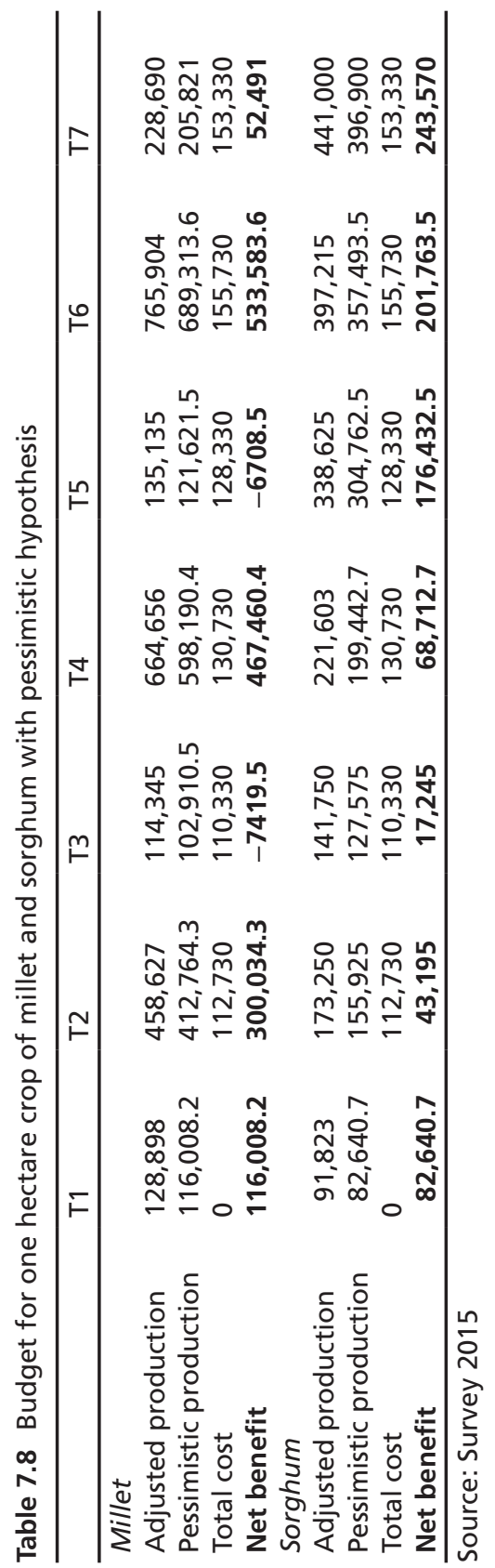


The main objective was to evaluate the most profitable opportunity for the application of water and soil conservation techniques.

Thus it is the combination of stony cords, water cuvettes, organic fertilizer, urea and NPK which makes it possible to obtain the highest benefit with millet cultivation. It is true that areas with low rainfall are recognized as suitable for growing millet; so, it is possible to improve agricultural performance not only financially but also physically in areas with a hard climate with better yields, protection of natural assets and an improved social fabric. It is also an alternative to adapting to climate change by sustainable and effective means.

\section{Appendix}

Table 7.9 Identification of higher treatments under millet and sorghum crops with pessimistic hypothesis

\begin{tabular}{lllllll}
\hline \multicolumn{2}{l}{ Mil } & \multicolumn{5}{l}{ Sorgho } \\
\cline { 2 - 7 } & $\begin{array}{l}\text { Variable } \\
\text { cost (FCFA) }\end{array}$ & $\begin{array}{l}\text { Net benefit } \\
\text { (FCFA) }\end{array}$ & Superior? & $\begin{array}{l}\text { Variable } \\
\text { cost (FCFA) }\end{array}$ & $\begin{array}{l}\text { Net benefit } \\
\text { (FCFA) }\end{array}$ & Superior? \\
\hline T1 & 0 & $116,008.2$ & Oui & 0 & $82,640.7$ & Oui \\
T2 & 112,730 & $300,034.3$ & Oui & 112,730 & 43,195 & Non \\
T3 & 110,330 & -7419.5 & Non & 110,330 & 17,245 & Non \\
T4 & 130,730 & $467,460.4$ & Oui & 130,730 & $68,712.7$ & Non \\
T5 & 128,330 & -6708.5 & Non & 128,330 & $176,432.5$ & Oui \\
T6 & 155,730 & $533,583.6$ & Oui & 155,730 & $201,763.5$ & Non \\
T7 & 153,330 & 52,491 & Non & 153,330 & 243,570 & Oui \\
\hline
\end{tabular}

Source: Survey 2015

Table 7.10 Comparison of higher treatments under millet and sorghum crops with pessimistic hypothesis

\begin{tabular}{lccl}
\hline & Total variable cost & Net benefit & Superior? \\
\hline T1 (millet) & 0 & $116,008.2$ & Oui \\
T2 (millet) & 112,730 & $300,034.3$ & Oui \\
T4 (millet) & 130,730 & $467,460.4$ & Oui \\
T6 (millet) & 155,730 & $533,583.6$ & Oui \\
T1 (sorghum) & 0 & $82,640.7$ & Non \\
T5 (sorghum) & 128,330 & $176,432.5$ & Non \\
T7 (sorghum) & 153,330 & 243,570 & Non \\
\hline
\end{tabular}

Source: Survey 2015 


\section{- Calculation of the yield adjusted by treatment}

Yield reduction of $10 \%$ to account for differences in management, harvesting pattern and parcel size between trial and actual environment.

\section{- Determination of the price of the product}

Source: Cereal Market Information System (SIM). Price of millet = $231 \mathrm{Fcfa} / \mathrm{kg}$ and Sorghum price $=175 \mathrm{Fcfa} / \mathrm{kg}$ (in 2015).

\section{- Variables cost}

Monetary variable costs:

Table 7.11 Cost of input

\begin{tabular}{lll}
\hline Fertilizers & Quantity $(\mathrm{Kg} / \mathrm{ha})$ & Cost per hectare $(\mathrm{F} / \mathrm{ha})$ \\
\hline Organic fertilization & 5000 & 6000 \\
Urea & 50 & 18,000 \\
NPK & 62.5 & 25,000 \\
\hline
\end{tabular}

Source: Survey 2015

Table 7.12 Cost of realization of zaï

\begin{tabular}{ll}
\hline Wording & Cost (FCFA/ha) \\
\hline Material & 4600 \\
Workforce & 25,000 \\
Total cost per hectare & 29,600 \\
\hline
\end{tabular}

Source: Estimate of the CES/AGF Program, 2015

Table 7.13 Cost of realization of half-moons

\begin{tabular}{ll}
\hline Wording & Cost (FCFA/ha) \\
\hline Material & 7200 \\
Workforce & 20,000 \\
Total cost per hectare & 27,200 \\
\hline
\end{tabular}

Source: Estimate of the CES/AGF du Programme, 2015 
Table 7.14 Cost of realization of stony ropes

\begin{tabular}{ll}
\hline Wording & Cost (FCFA/ha) \\
\hline Transport & 29,545 \\
Opening of trenches & 6185 \\
Tracking fees & 5600 \\
Small material & 5800 \\
Workforce & 30,000 \\
Total cost per hectare & 77,130 \\
\hline
\end{tabular}

Source: Estimate of the CES/AGF du Programme, 2015

\section{Notes}

1. Botoni and Reij 2009, Silent transformation of the environment and production systems in the Sahel: Impacts of public and private investments in the management of natural resources.

2. National Institute of Statistics and Development.

3. Data in Appendix (Tables 7.11, 7.12, 7.13, and 7.14).

4. See Table 7.9 in Appendix.

5. See Table 7.10 in Appendix.

\section{References}

Abramovay, R. (2002). Crédit rural et politiques publiques dans le sertão brésilien. Revue Tiers Monde, 43(172), 761-782.

Barro, A., Zougmoré, R., \& Taonda, S. J. B. (2005). Mécanisation de la technique du zaï manuel en zone semi-aride. Cahiers Agricultures, 14(6), 549-559.

Baumgart-Getz, A., Prokopy, L., \& Floress, K. (2012). Why Farmers Adopt Best Management Practice in the United States: A Meta-Analysis of the Adoption Literature. Journal of Environmental Management, 96, 17-25.

Botoni, E., \& Reij, C. (2009). La transformation silencieuse de l'environnement et des systèmes de production au Sahel: impact des investissements publics et privés dans la gestion des ressources renouvelables. Centre for International Coopération (CIS) \& Comité Permanent inter-Etats de Lutte contre la Sécheresse dans le Sahel (CILSS), Rapport, p. 63.

Bourdon, M. (1994). Faut-il craindre une agriculture capital-saving? Économie rurale, 219,24-27.http://www.persee.fr/docAsPDF/ecoru_0013-0559_1994_ num_219_1_4589.pdf. 
Dibouloni, J. B. (2004). Analyse de l'adoption des techniques du Zaï et des cordons pierreux dans les régions du Centre et du Centre-Sud (65p). Mémoire IDR, Université Polytechnique de Bobo Dioulasso.

FAO. (2010). Les implications du changement climatique pour le développement agricole et la conservation des ressources naturelles en Afrique. Nature and Faune, 25(1), 2026-5824.

Ganaba, S. (2005). Impact des aménagements de conservation des eaux et des sols sur la régénération des ressources ligneuses en zone sahélienne et nord soudanienne du Burkina Faso. VertigO, 6(2).

Gedikoglu, H., \& McCann, L. (2007). Impact of Off-Farm Income on Adoption of Conservation Practices. Selected Paper at the American Agricultural Economics Association Annual Meeting, Portland, OR, p. 28.

Gedikoglu, H., McCann, L., \& Artz, G. (2011). Off-Farm Employment Effects on Adoption of Nutrient Management Practices. Agricultural and Resource Economics Review, 40(2), 293-306.

IFPRI. (2009). Changement climatique Impact sur l'agriculture et coûts de l'adaptation. ISBN: 978-0-89629-536-0. Retrieved from http://www.ifpri. $\mathrm{org} /$ publication/climate-change- 1 .

IPCC. (2014). Climate Change: Synthesis Report. Contribution of Working Groups I, II and III to the Fifth Assessment Report of the Intergovernmental Panel on Climate Change [Core Writing Team, R. K. Pachauri, \& L. A. Meyer (eds.)]. Geneva: IPCC. p. 151.

Kini, J. (2007). Analyse des déterminants de l'adoption des technologies de conservation des eaux et des sols dans le plateau central du Burkina Faso. Mémoire de DEA, Université de Ouagadougou, Burkina Faso.

Lompo, F., \& Ouédraogo, S. (2006). Rapport de l'étude pilote d'évaluation de l'impact des recherches en GRN en zone Sahélienne de l'Afrique de l'ouest 23, p. 9.

Mariano, M. J., Villano, R., \& Fleming, E. (2012). Factors Influencing Farmers' Adoption of Modern Rice Technologies and Good Management Practices in the Philippines. Agricultural Systems, 110, 41-53.

National Institute of Statistics and Development. (2015). National Statistical Yearbook 2015.

Ouédraogo, S. (2005). Intensification de l'agriculture dans le plateau central au Burkina Faso: Une analyse possibilités à partir de nouvelles technologies. Retrieved from http://dissertations.ub.rug.nl/files/faculties/eco/2005/s.ouedraogo/titlecon 2008.

Ouédraogo, S., Belemvire, A., Maiga, A., Sawadogo, H., \& Savadogo, M. (2008). Etude sahel Burkina Faso: Evaluation des impacts biophysiques et socio- 
économiques des investissements dans les actions de gestion des ressources naturelles au nord du plateau central du Burkina Faso. Rapport d'études, p. 94.

Pontanier, R., et al. (1995). L'Homme peut-il refaire ce qu'il a défait? (John Libbey Eurotext ed.pp. 179-188).

Rodríguez-Entrena, M., \& Arriaza, M. (2013). Adoption of Conservation Agriculture in Olive Groves: Evidences from Southern Spain. Land Use Policy, 34, 294-300.

Roose, E., Kaboré, V., \& Guenat, C. (1993). Le zaï: fonctionnement, limites et amélioration d'une pratique traditionnelle africaine de réhabilitation de la végétation et de la productivité des terres dégradées en region soudano-sahélienne (Burkina Faso). In Spécial érosion: réhabilitation des sols et GCES. Cahiers ORSTOM. Série Pédologie, 28 (2), 159-173. ISSN 0029-7259.

Samuelson, P. A. (1954). The Pure Theory of Public Expenditure. The Review of Economics and Statistics, 36(4), 387-389.

Sanogo, M. (2012). Capitalisation des bonnes pratiques de gestion durable des terres pour l'adaptation à la variabilité et au changement climatique au Mali: analyse d'impacts agronomiques environnementaux et socio-économiques. Centre régional AGRHYMET, mémoire, p. 84.

Sawadogo, H. (2008). Restauration des potentialités de sols dégradés à l'aide du zaï et du compost dans le Yatenga Burkina Faso. Biotechnology Agronomy Society Environment, 12(3), 279-290.

Thiombiano, L. (2000). Etude de l'importance des facteurs édaphiques et pédopaysagiques dans le développement de la désertification en zone sahélienne du Burkina Faso. Thèse d'Etat, 1, 209.

Open Access This chapter is licensed under the terms of the Creative Commons Attribution 4.0 International License (http://creativecommons.org/licenses/ by/4.0/), which permits use, sharing, adaptation, distribution and reproduction in any medium or format, as long as you give appropriate credit to the original author(s) and the source, provide a link to the Creative Commons license and indicate if changes were made.

The images or other third party material in this chapter are included in the chapter's Creative Commons license, unless indicated otherwise in a credit line to the material. If material is not included in the chapter's Creative Commons license and your intended use is not permitted by statutory regulation or exceeds the permitted use, you will need to obtain permission directly from the copyright holder.

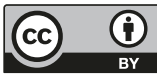

